\title{
Fatal drowning statistics from the Netherlands - an example of an aggregated demographic profile
}

\author{
Joost Bierens ${ }^{* *}$ (D) and Jan Hoogenboezem² ${ }^{2}$
}

\begin{abstract}
Introduction: Incompleteness of fatal drowning statistics is a familiar problem impeding public health measures. Part of the problem may be that only data on accidental drowning are used and not the full potential of accessible data.
\end{abstract}

Methods: This study combines cause-of-death certificates and public prosecutor's court documents between 1998 and 2017 to obtain an aggregated profile. Data are also used as a basis for a trend analysis.

Results: The dataset includes 5571 drowned persons (1.69 per 100,000). The highest risk group are persons above the age of 50. Demographic differences are observed between suicide by drowning, accidental drowning, and drowning due to transportation $(0.72,0.64,0.28$ per 100.000) and between native Dutch, and Dutch with western and nonwestern background $(1.46,1.43,1.76$ per 100.000). Non-residents account for another $12.2 \%$. When comparing the periods 1998-2007 with 2008-2017, the Standard Mortality declines for suicide drowning and accidental drowning among persons with a native Dutch and non-western background. Single regression analysis confirms a decrease of drowning over the full period, breakpoint analysis shows an increase in the incidence of the total number of drowning, suicide by drowning and accidental drowning starting in 2007, 2008 resp. 2012.

Discussion: Compared to the formal number of fatal accidental drowning in the Netherlands $(n=1718$; incidence 0.52 per 100,000), the study identifies 350\% more drowning. Differences in demographic data and the recent increase needs to be explored for public health interventions.

Keywords: Demographic, Drowning, Suicide, Transportation, Ethnicity, Trend

\section{Introduction}

The Global Report on Drowning, published in 2014 by the World Health Organisation (WHO), suggests that formal national data underrepresent the full fatal drowning toll by up to $50 \%$ in some high-income countries and up to $400-500 \%$ in low and middle-income countries $[1,2]$. A lack of reliable national data on drowning has been recognised for over the past two decades. Multiple

\footnotetext{
*Correspondence: jbierens@euronet.nl

1 Research Group Emergency and Disaster Medicine, Vrije Universiteit Brussels, Laarbeeklaan 103, 1090 Brussels, Belgium

Full list of author information is available at the end of the article
}

reasons have been identified to explain this [3-7], including the absence in the national data of fatal drowning by suicide, transportation accidents, natural disasters such as floods [8-11], cyclones [12], tsunamis [13, 14] as well as disasters with ferryboats, cruise ships and migrant crafts [14]. Another explanation for the lack of reliable national data is the exclusion of non-inhabitants such as foreign students, workers, tourists and migrants [15-20] in the national statistics and low quality of data registration and collecting systems [10, 21,22]. The update in 1990 of the International Classification of Diseases (ICD) from ICD-9 to ICD-10 may have further limited the 
opportunities to obtain representative national and international data on drowning, although the effect is considered small $[6,23,24]$.

A complete and reliable picture of the total burden of fatal, and also non-fatal, drowning is needed to monitor current and future trends [20,22, 25-27], to understand the impact of various prevention programmes [20,26, 28] and to become timely informed about the acute health effects in the aquatic environment of countries affected by climate change or other reasons of instability [29]. This may also paradoxically become important now that recent statistics show a sudden and unexplained decrease in drowning rates [30].

Studies that provide evidence of the suggested weakness of data on drowning are scarce [2, 23, 31-33]. This study was initiated with the aim of identifying the complete burden of fatal drowning in one European country, including suicides, transportation accidents and non-residents who drowned fatally while in the Netherlands. The characteristics of the various groups were explored. Comparison of the data between 1998 and 2007 and between 2008 and 2017, as well as trend analysis and breakpoint analysis over the period 1998-2017, allowed the identification of trends over the last 20 years. The methodology used, provides a standardised method that may serve as an example to obtain a more complete profile of drowning, and their trends, in countries with a well-functioning cause of death registration.

\section{Material and methods}

\section{Setting}

Statistics Netherlands (CBS) is responsible for collecting, compiling, producing and publishing causes of death statistics [34]. For every deceased person registered in the Personal Records Database (Basis Registratie Personen: BRP) of the Netherlands, an attending medical practitioner or a forensic doctor appointed by the municipality is obliged by law to complete a Medical Certification of Cause-of-Death (MCCD). The MCCD distinguishes between natural and non-natural (also known as external) causes. In non-natural (external) causes of death, the event directly leading to the death is considered the underlying cause of death. The resulting injury is the code of injury. Based on the MCCD, the underlying causes of death and the codes of injury are encoded in accordance with the tenth revision of the International Statistical Classification of Diseases and Related Health Problems (ICD-10) of the World Health Organisation (WHO). When a MDDC is unclear or incomplete, the certifier is contacted.

For each deceased registered in the BRP, a check is performed whether a MDDC has been received by CBS. More than $99 \%$ of the records can be linked to the corresponding MDDC and are then coded based on the ICD-10. For a person registered in the BRP who died abroad, there is usually no death certificate and therefore this is almost always recorded as "Other ill-defined and unspecified causes of mortality" (R99, ICD-10).

In addition, for each case of non-natural death, a court document is created by regional Public Prosecutor's Offices (PPO). Statistics Netherlands (CBS) investigates such documents and the relevant data related to the cause of death are filled out in a standardised questionnaire that includes information, e.g. on the cause of drowning. In order to optimise the quality of cause- ofdeath statistics on persons included in the BRP, data from MDDC and court files are combined with CBS data. If needed, data are corrected until both documents contain identical and plausible information before becoming finalised. The PPO court also produces documents with the non-natural causes of death of all non-residents and people with no fixed place of residence.

\section{Definitions}

In this study, the formal definitions by the CBS are used.

\section{Resident in the Netherlands}

A person living in the Netherlands who is registered in the BRP.

\section{Resident with a migration background}

A person living in the Netherlands who has at least one parent who was born outside the Netherlands. A person with a Western migration background has at least one parent born in another country in Europe (excluding Turkey), North America, Oceania, Indonesia or Japan. A person with a non-Western migration background has at least one parent born in a country in Africa, Latin America or Asia (excluding Indonesia and Japan) or Turkey [35].

\section{Non-residents in the Netherlands}

A person not living in the Netherlands or living in the Netherlands for less than 4 months; a non-resident is not registered in the BRP. Non-residents include tourists and other foreign visitors in the Netherlands; persons who temporarily work or study in the Netherlands; undocumented immigrants and asylum seekers who stay in the Netherlands.

\section{Building up the data file}

This study includes all persons who died in the period 1998 to 2017 with drowning as the injury code T75.1 (ICD-10), regardless of the underlying cause of death (external cause). In this way, in addition to accidental drowning (W65-W74), also drowning were included 
by intentional self-harm, such as suicide by drowning (X60-X84), transport accidents (V01-V99) and a remaining group with various causes (A00-Y99). The latter group includes the residual group of drowning: by murder or manslaughter; persons of whom it is unknown whether they either accidentally or intentionally drowned; persons who died more than 30 days after the drowning accident; late effects of drowning; persons who drowned after an epileptic seizure; and who drowned after falling through the ice.

CBS began to use the ICD-10 in 1996. The CBS data of all fatal drowning of residents that occurred in the Netherlands from 1998 until 2017 were included in the data file. For non-residents who drowned in the Netherlands, the data files selected from the PPO documents were added. For the analysis described in this publication, only the data on gender, date of birth, manner of drowning, country of origin and date of death have been used.

\section{Presentation of the data}

Data on deaths by drowning are presented in absolute numbers, incidence per 100,000 of the average population, Standard Mortality (SM) and Standard Mortality Ratio (SMR). The average population is the mean of the population as at 1 January and as at 31 December of the same year. The incidence in a year is the total number of confirmed deaths divided by the average population over the same period per 100,000 population.

In the total number of deaths by drowning in the Netherlands, non-residents are included. There is no data on the complete population of non-residents, since this population varies greatly throughout the year, for example due to tourism or seasonal labor.

Data considered essential for the purpose of the study are reported in the manuscript. Supportive data are included in Supplementary Tables.

\section{Standard mortality and standard mortality ratio}

In the period 1998-2017, the age composition of the population with a native Dutch background is different from age composition of the population with a western or non-western migration background. For this reason, data of this period from the population with a western or non-western migration background are also presented as age-adjusted incidence per 100,000 of the population according to the age composition of the population with a native Dutch background. This is the Standard Mortality (SM) The SM for persons with a migration background is calculated by the formula

$$
S M^{(x)}=100,000 \times \frac{D^{(\text {native })}}{N^{(\text {native })}} \times \frac{D^{(x)}}{\sum_{i} N_{i}^{(x)} \frac{D_{i}^{(\text {(native })}}{N_{i}^{(\text {native })}}}
$$

where $D_{i}^{(x)}$ are the number of deaths in age group $i$ and $N_{i}^{(x)}$ the size of the population in age group i with persons with migration background $x$. The symbols without subscript $i$ are the totals over all age groups.

When comparing the periods 2008-2017 with 19982007, the age compositions of each of the populations with a native Dutch, western and non-western migration background is different between the two periods. For this reason, data of the age compositions in the period 20082017 are also presented as age-adjusted incidences per 100,000 of the population (SM) compared to the population with the same background in the period 1998-2007 (f.e. non-western 2008-2017 vs non-western 1998-2007).

In the period 1998-2017, to allow an alternative comparison between age groups and populations, data are also presented as Standard Mortality Ratio (SMR). The SMR is 1 for drowning of the population with a Dutch background between 1998 and 2017. When comparing the age distribution of the native Dutch population with the western and non-western migration background population, a SMR that is smaller or larger than 1, implicates less or more drowning in the age group of the western and non-western migration background population over the period 1998-2017 compared to the Dutch population.

When comparing the periods 2008-2017 with 19982007, the SMR is set at 1 for each population in the period 1998-2007. A SMR over the period 2008-2017 that is smaller or larger than 1 , implicates less or more drowning in the populations with the same background. SMR data are included in the additional files as supplementary table to Fig. 2 and Table 2, as well as in the supplementary Tables 3 and 4 .

\section{Statistical analysis}

Most data in this study are presented as descriptive data. Statistical analysis has only been applied to analyse differences in migration backgrounds and calculations of trends. T-tests have been applied for differences between the migration background and the comparison between 1998 and 2007 and 2008-2017. For all calculations, $p<0.05$ was considered statistically significant.

For the trend analysis of the total period 1998-2017, single linear regression analysis has been used. To determine whether there are multiple trends with breakpoints, piecewise regression has been used. Before the breakpoint analysis, outliers identified with Cook's Distance statistics have been excluded. Programming language R from the statistical package Segmented (https:// 
cran.r-project.org/web/packages/segmented/segmented. pdf) has been used for breakpoint analysis.

\section{Ethics committee}

The data in this study contains aggregated and coded information on age, gender and cause(s) of death, and cannot be traced back to a deceased person. The coded information based on the MDDC is published annually in cause-of-death statistics. This study is a secondary analysis involving no identifiable patient data and no ethical restraints were applicable.

\section{Results}

\section{The aggregated data}

5571 people fatally drowned in the Netherlands (incidence: 1.69 per 100,000) between 1998 and 2017. In the total group, the average age is 50.8 years. There are 3914 men (70.3\%; average age 48.7 years; incidence 2.40 per 100,000$)$ and 1657 women (29.7\%; average age 55.6 years; incidence 1.00 per 100,000$)$. Three main causes (accidental drowning, suicide by drowning and transport accidents with drowning) have been compared and demonstrate different characteristics in terms of total number, incidence per 100,000, age and gender distributions (Fig. 1a and b, Table 1 ). A residual group with various causes $(n=183 ; 3.3 \%$ of the total; 0.06 per 100,000 ) is included in the overall analysis but not included in the analysis of the three main causes of drowning. In this period, no fatal drowning was recorded as a result of a natural disaster, such as during the several floods that occurred in this period. Details of the aggregated data are available as Supplementary Table to Fig. 1 and Table 1.

\section{Drowning by migration background}

Of the total 5571 drownings, 4892 (87.8\%; 1.49 per $100,000)$ were residents of the Netherlands. Of these, $78.5 \%$ ( $n=3840 ; 1.46$ per 100,000$)$ have a native Dutch background; $8.7 \%(n=427 ; 1.43$ per 100,000$)$ have a Western migration background and $12.8 \%(n=625 ; 1.76$ per 100,000) a non-Western migration background. In addition, 679 non-residents drowned $(12.2 \%$ of the total number). The size of the total population of persons nonresiding in the Netherlands is not known and the incidence cannot be calculated. Drowning of residents with various migration backgrounds, and non-residents who drown in the Netherlands, have different characteristics in terms of age, gender, and cause of death.

The SM of all drowned persons with a non-western migration background is almost twice as high as the persons with a western migration or native Dutch background (2.70 vs. 1.44 and 1.46 per 100,000). Similar differences in the SM between the migration backgrounds are observed in suicide and accidental drowning, but not in transport accidents.

When comparing the different migration backgrounds by age group, the overall picture is that the incidence by age group is rather similar between persons with native Dutch background and a western migration background until the age of 70 years. The incidence among persons with a western migration background is significantly higher in four age groups and significantly lower in six age groups (Fig. 2 and Table 2).

When comparing between persons with a native Dutch background and a non-western background, the differences are much larger. The incidence in persons with a non-western background is significantly higher in 16 age groups and lower in two age groups. The largest difference in the total group of drowning is found in the groups 0-9 years, mainly caused by the higher incidence of accidental drowning (0.59 versus 1.56 per 100,000$)$; this is 2.7 times higher than among persons with a native Dutch background. The large difference in the age 10-19years is caused by the higher incidence of drowning by suicide (0.02 vs. 0.21 per 100,000$)$ and accidental drowning $(0.14$ versus 0.71 per 100,000$)$. This is 10.8 and 5.1 times higher respectively than among persons with a native Dutch background.

Details of the data related to migration background are available as a Supplementary Table to Fig. 2 and Table 2 .

\section{Trends}

The highest absolute number of drowning in the total group occurred in 2002 (331; 2.05 per 100,000), the lowest in 2007 (231; 1.41 per 100,000 (Fig. 3). Additional data on the absolute numbers is available in Supplementary Table to Fig. 3.

In terms of the incidence, over the complete period of the study (1998-2017), there is a decreasing trend of all drowning (adjusted $R^{2}: 0.40$ ), suicidal drowning (adjusted $\mathrm{R}^{2}$ : 0.15), accidental drowning (adjusted $\mathrm{R}^{2}: 0.26$ ) and drowning due to transportation (adjusted $R^{2}$ : 0.03) (Fig. 4).

Fig. 4 also shows a breakpoint in the trends of the incidence for all drowning in 2007 (adjusted $R^{2}$ : 0.70; before 2007: level 85.3, slope-4.2\%; after 2007: level - 23.6, slope $1.3 \%)$. For drowning by suicide, a breakpoint is identified in 2008 (adjusted $R^{2}$ : 0.66; before 2008: level 65.7, slope-3.3\%; after 2008: level-21.5, slope $1.1 \%)$. For accidental drowning there are 2 breakpoints. In $2002\left(\mathrm{R}^{2}: 0.55\right.$; before 2002: level-27.7, slope 1.4\%; after 2002: level 52.4, slope-2.6\%) and in 2012 (before 2012: level 52.4, slope-2.6\%; after 2012: level-40.9, slope $2.1 \%$ ). There is no breakpoint identified 


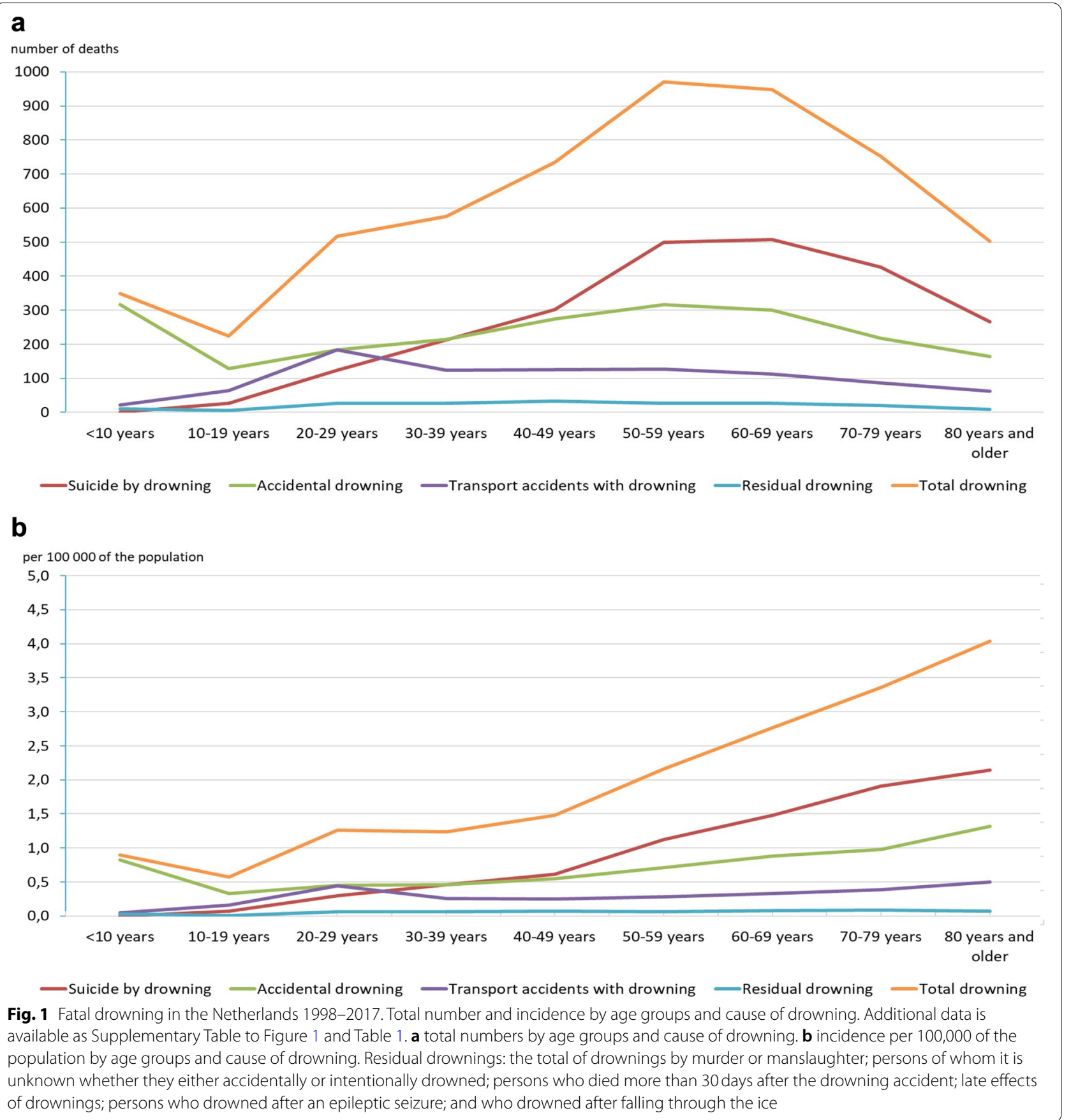

for drowning due to transportation $\left(R^{2}: 0,51\right.$, level 3.1, slope $-1.0 \%)$. Details of the trends and breakpoints are available as Supplementary Table to Fig. 4.

When comparing the SM and SMR of the total group and the three causes of drowning between 2008 and 2017 $(n=2658)$ with the previous decade 1998-2007 $(n=2886)$, a significant decrease can be observed. The share of female drowning victims did not significantly change between the two periods (Table 3) Furthermore, the SM and SMR of all causes of drowning for residents with native Dutch and non-western backgrounds decreases significantly in the recent decade. The same pattern is identified for suicide by drowning and accidental drowning. There was no significant decrease for people with a western background, both regarding the total group and the 3 causes studied (Table 4). 
Table 1 Fatal drowning in the Netherlands 1998-2017. Comparison between the three main causes of drowning. Additional data on age groups is available as Supplementary Table to Figure 1 and Table 1

\begin{tabular}{|c|c|c|c|}
\hline 1998-2017 & Suicide by drowning & Accidental drowning & Transport accidents with drowning \\
\hline Number of drownings & 2366 & 2117 & 905 \\
\hline Percentage of total drowning & $42.5 \%$ & $39.1 \%$ & $16.2 \%$ \\
\hline Incidence per 100,000 & 0.72 & 0.64 & 0.28 \\
\hline Male / female & 1.44 & 3.80 & 3.92 \\
\hline Average age & $58.7 \mathrm{yrs}$ & $44.5 \mathrm{yrs}$ & $45.7 \mathrm{yrs}$ \\
\hline $\begin{array}{l}\text { Age group with the highest number } \\
\text { of deaths }\end{array}$ & $\begin{array}{l}60-69 y r s .(n=508) \\
\text { incidence } 1.48\end{array}$ & $\begin{array}{l}0-9 y r s .(n=316) \text { and } 50-59 y r s .(n=316) \\
\text { incidence } 0.82 \text { and } 0.71 \text { resp. }\end{array}$ & $\begin{array}{l}20-29 y r s .(n=183) \\
\text { incidence } 0.44\end{array}$ \\
\hline $\begin{array}{l}\text { Age group with the lowest number } \\
\text { of deaths }\end{array}$ & $0-9 y r s .(n=0)$ & $10-19 y r s .(n=129)$ & $0-9 y r s .(n=21)$ \\
\hline Age group with the highest incidence & $\begin{array}{l}80+\text { yrs. }(n=267) \\
\text { incidence } 2.14\end{array}$ & $\begin{array}{l}80+\text { yrs. }(n=165) \\
\text { incidence } 1.32\end{array}$ & $\begin{array}{l}80+\text { yrs. }(n=62) \\
\text { incidence } 0.50\end{array}$ \\
\hline Age group with the lowest incidence & $\begin{array}{l}0-9 y r s .(n=0) \\
\text { incidence } 0.00\end{array}$ & $\begin{array}{l}\text { 10-19yrs. }(n=129) \\
\text { incidence } 0.33\end{array}$ & $\begin{array}{l}0-9 y r s .(n=21) \\
\text { incidence } 0.05\end{array}$ \\
\hline
\end{tabular}

Values represent absolute numbers with percentages and incidence per 100,000 population stratified by causes of drowning and age groups

Comparing the periods $1998-2007$ and 2008-2017 in terms of age-related and cause-related incidences, a scattered pattern emerges (Fig. 5). There are 2 significantly increased incidences: accidental drowning among 20 to 29-year-olds and drowning in transport accidents among 70-79-year-olds. For all other causes and ages, the incidence has remained the same or is significantly reduced. For the total group, significant reductions are observed for the 0-9 and 40-69years old. The drop in the share held by the group 0-9years is mainly due to a decline in accidental drowning in this age group. The decline in the group 40-69 years is largely caused by a significant decline in suicide by drowning and accidental drowning in that age group. Details of the trend data are available as Supplementary Table to Fig. 5 and as Supplementary Tables 3 and 4.

\section{Discussion}

To our best knowledge, this is the first study based on unrestricted direct access to all existing data in the national death statistics that was able to depict an ascomplete-as-possible profile of the national drowning mortality. Historically experienced problems to obtain these data were most of all solved by direct cooperative involvement of the department in charge of death statistics at the CBS.

The formal, officially recognised and often cited, total number of deaths by drowning in the Netherlands between 1998 and 2017 is 1718; about 85 fatal drownings per year [36, 37]. The number is based on accidental drowning by Dutch residents. To obtain the complete number of drowning, this study was extended to all causes of drowning and at the same time to drowning by non-residents. In this way, the aggregated and complete profile of drowning could be identified, which included
5571 drownings; approximately 275 fatal drownings per year. The currently published incidence of accidental drowning by Dutch residents is 0.52 per 100,000 of the population. With this method, the incidence increases to 1.69 per 100,000 of the population, an increase of almost $350 \%$.

For over two decades, there have been discussions about the real number of fatal and non-fatal drowning worldwide. Already at the end of the previous century, several publications demonstrated concern that the common way of reporting drowning statistics underestimates the actual numbers [3-6, 38]. For example, the first World Congress on Drowning was being prepared with the motivation that "each year an estimated number of 150,000 people die from drowning. At least the same number of victims (but probably 2-20 times that number) are admitted to hospitals for observation and treatment" [39]. This number appears to be an underestimation when, in 1999, the WHO published a report in which the total burden of drowning is estimated to affect 1.1 million people [40]. The report identifies drowning as the third largest cause of death by unintentional injury and estimates that drowning constitutes $8 \%$ of the injury deaths in the world. The same report acknowledges that reliable numbers are missing from many countries, and particularly in low and middle-income countries underestimations are reported due to imprecise data. In 2004, the United National International Children's Emergency Funds (UNICEF) together with The Alliance for Safe Children (TASC) observes that most drowning victims are never brought to a hospital and therefore not included in the information systems of low and middleincome countries that report on mortality) [41]. In 2008, the WHO together with UNICEF stated that the quality 


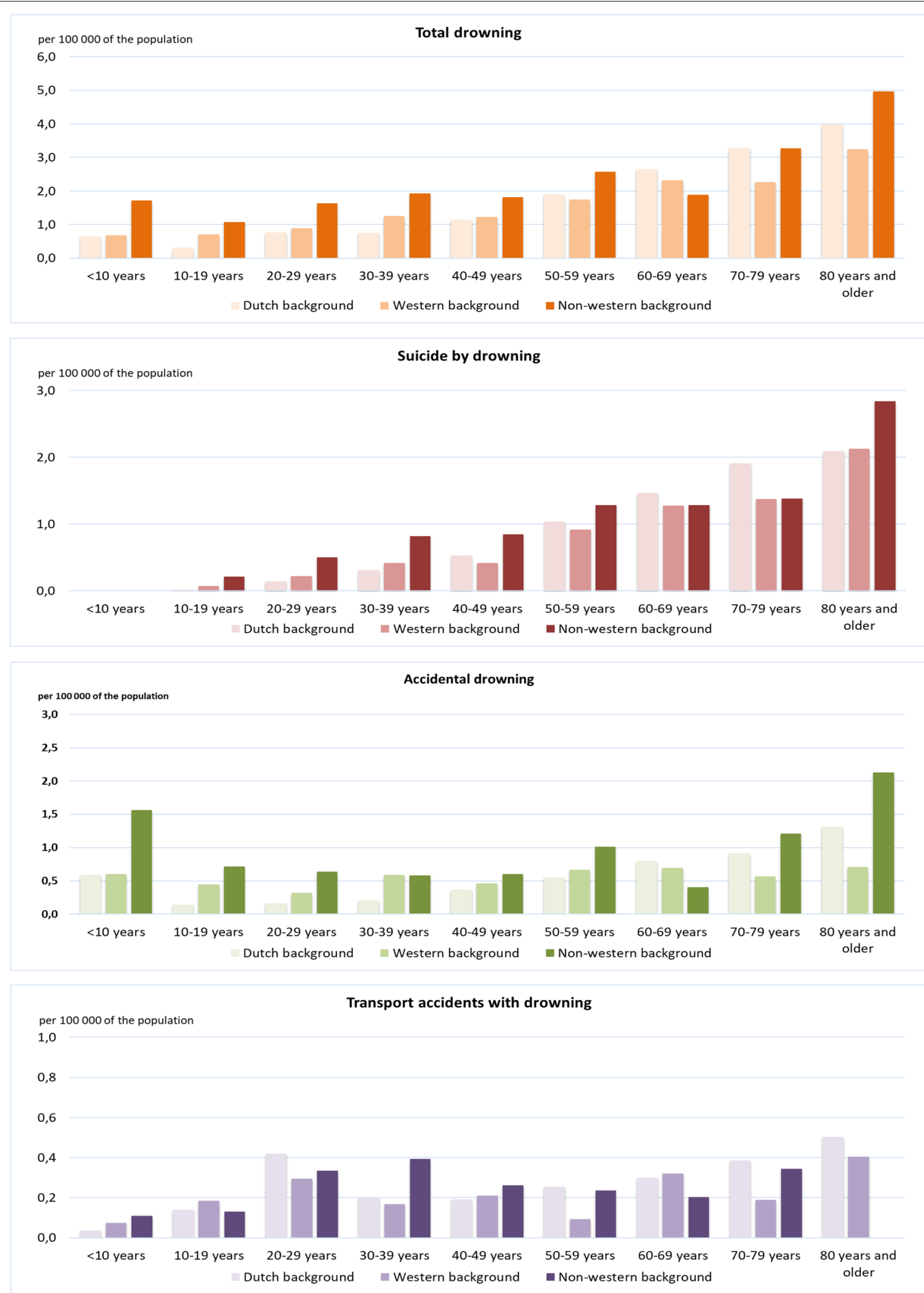

Fig. 2 Fatal drowning in the Netherlands 1998-2017. Incidence per 100,000 of the population by cause of drowning, migration background and age group. Additional information on Standard Mortality, Standard Mortality Ratio, Deviation Rate and 95\% Confidence Interval is available as Supplementary Table to Figure 2 and Table 2 
Table 2 Fatal drowning in the Netherlands 1998-2017: Comparison between migration backgrounds and non-residents. Additional data on the incidence per 100,000 population by cause of drowning, migration background and age is available as Supplementary Table to Figure 2 and Table 2

\begin{tabular}{|c|c|c|c|c|}
\hline \multirow[b]{2}{*}{ 1998-2017 } & \multicolumn{3}{|c|}{ Residents of the Netherlands } & \multirow{2}{*}{$\begin{array}{l}\text { Non-residents of } \\
\text { the Netherlands }\end{array}$} \\
\hline & $\begin{array}{l}\text { Native Dutch } \\
\text { background }\end{array}$ & Western background & $\begin{array}{l}\text { Non-western } \\
\text { background }\end{array}$ & \\
\hline \multicolumn{5}{|l|}{ Total drowning } \\
\hline Number of drownings & 3840 (68.9\%) & $427(7.7 \%)$ & $625(11.2 \%)$ & $679(12.2 \%)$ \\
\hline Incidence per 100,000 & 1.46 & 1.43 & 1.76 & - \\
\hline Standard Mortality & 1.46 & 1.44 & $2.70^{*}$ & - \\
\hline Average age at death & $55.6 \mathrm{yrs}$ & $50.2 \mathrm{yrs}$ & $32.5 \mathrm{yrs}$ & $40.7 \mathrm{yrs}$ \\
\hline Male / female & 2.1 & 2.2 & 3.3 & 4.9 \\
\hline \multicolumn{5}{|l|}{ Suicide by drowning } \\
\hline Number of drownings & 1803 & 185 & 209 & 169 \\
\hline Percentage of total drownings & $47.0 \%$ & $43.3 \%$ & $33.4 \%$ & $24.9 \%$ \\
\hline Incidence per 100,000 & 0.68 & 0.62 & 0.59 & - \\
\hline Standard Mortality & 0.68 & 0.62 & $1.16^{*}$ & - \\
\hline Average age at death & $61.9 \mathrm{yrs}$ & $58.4 \mathrm{yrs}$ & $42.6 y r s$ & $44.3 \mathrm{yrs}$ \\
\hline \multicolumn{5}{|l|}{ Accidental drowning } \\
\hline Number of drownings & 1257 & 163 & 298 & 399 \\
\hline Percentage of total drownings & $32.7 \%$ & $38.2 \%$ & $47.7 \%$ & $58.8 \%$ \\
\hline Incidence per 100,000 & 0.48 & 0.55 & 0.84 & - \\
\hline Standard Mortality & 0.48 & $0.57^{*}$ & $1.15^{*}$ & - \\
\hline Average age at death & $50.9 \mathrm{yrs}$ & $43.5 \mathrm{yrs}$ & $25.3 \mathrm{yrs}$ & $38.8 \mathrm{yrs}$ \\
\hline \multicolumn{5}{|l|}{ Transport accidents with drowning } \\
\hline Number of drownings & 647 & 60 & 87 & 111 \\
\hline Percentage of total drownings & $16.8 \%$ & $14.1 \%$ & $13.9 \%$ & $16.3 \%$ \\
\hline Incidence per 100,000 & 0.25 & 0.20 & 0.24 & - \\
\hline Standard Mortality & 0.25 & 0.20 & 0.28 & - \\
\hline Average age at death & $48.1 \mathrm{yrs}$ & $43.7 \mathrm{yrs}$ & $32.9 \mathrm{yrs}$ & $42.0 \mathrm{yrs}$ \\
\hline
\end{tabular}

--- The total non-resident population is not known and therefore the incidence and the Standard Mortality cannot be calculated

* The Standard Mortality (SM) is significantly higher compared to the other migration backgrounds (t-test: $p<0.05$ )

of the mortality data of injuries tends to be weakest where the problems are greatest [42]. In 2012, UNICEF together with The Working Group on Child Drowning in Lowand Middle-Income countries published a report on child drowning that attempts to overcome earlier encountered structural, cultural, societal, legal and financial problems in data collection and data coding at the national level by capturing data at local level by means of verbal autopsies: interviews in selected households and communities. They concluded that there is $58-330 \%$ of underreporting [43]. In 2014, the WHO Global Report on Drowning pointed out that inaccurate coding and poor data collection systems obscure the full scale of global drowning [1]. In 2017, another study concluded that the specificity, and thus quality, in drowning method reporting varied across countries [38]. A recent drowning publication based on the Global Burden of Disease 2017 study estimates that ICD codes for accidental drowning account for $40-50 \%$ of all drowning in high-income countries [2].
In the same period, from 2002 onwards, researchers from several countries have tried to compile all-inclusive and complete data on fatal drowning. These populationbased studies from France [44], the Netherlands [45], Australia, Canada and New Zealand [20, 26, 27, 46, 47], Tanzania [48], China [24], Fiji [49], Philippines [14], Iran [50], and Czech Republic [51] conclude that 3 to 13 data sources need to be merged in order to obtain a complete picture of the fatal national drowning data. Each of these studies recognises major problems. These problems include data collection limited to a restricted period of the year, poor quality of the definitions used, nomenclature, categorisation, coding and coding hierarchy of the data, availability of data that are only retrievable after a long complex and costly procedure, poor compliance of those who have to provide the data information to the system and low priority to the issue of drowning. Another cause of incomplete data is the result of the large portion of drowning of undetermined intent or open verdict 


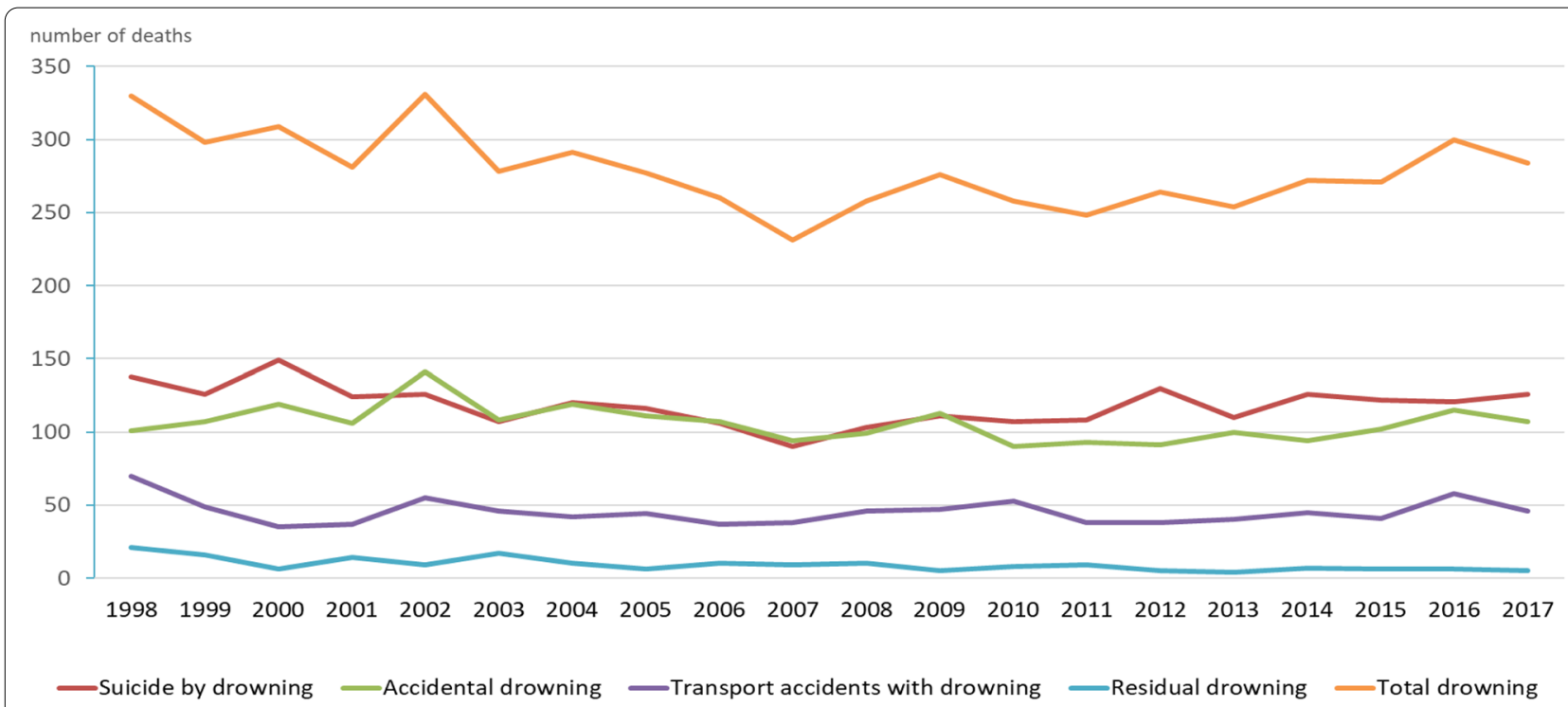

Fig. 3 Fatal drowning in the Netherlands 1998-2017; trend of total number by year and cause of drowning. Additional information on Incidence, Standard Mortality, Standard Mortality Ratio, Deviation Rate and 95\% Confidence is available as Supplementare Table to Figure 3. Residual drownings: the total of drownings by murder or manslaughter; persons of whom it is unknown whether they either accidentally or intentionally drowned; persons who died more than 30 days after the drowning accident; late effects of drownings; persons who drowned after an epileptic seizure; and who drowned after falling through the ice

by forensic pathologists and forensic doctors about the cause of drowning [52-54].

Most of these studies recognise that by only including accidental drowning, large numbers of drowning are excluded from the official statistics. For this reason, to obtain a more complete picture, a study from the Philippines includes transportation accidents (V90-92) and natural disasters (X-38), and concludes that the incidence of drowning in this way increases from 6.0 to 8.5 per 100,000 population [14]; a study in Tanzania, including the full range of drowning related ICD-10 codes, concludes that the drowning mortality is $16 \%$ higher than previously considered [47]. Australian studies including multiple drowning codes and triangulation found an increase of $40 \%$ [26, 27]. Using a capture-recapture method, the mortality from drowning increased from 4.5 to 8.3 per 100.000 in 2 Northern-Iran provinces [50].

The information below provides more detailed information on causes, demographical characteristics and trends from this study, as well as their relationship with international data. All these data had not been available before; they provide new and unrecognised aspects of the fatal drowning profile that may be used for public health interventions.

\section{Suicide}

This study shows that the largest contribution in terms of absolute numbers $(n=2366)$ and incidence $(0.72$ per
$100,000)$ is made by suicidal drowning. Previous studies on suicidal drowning were concerned with underreporting of drowning by suicide and it being misclassified as accidental drowning [55-57] or transportation accidents [4]. We believe that there is very limited underreporting in this study because data on the death certificate are carefully compared with the information provided in the court document by the PPO.

The portion of $42.5 \%$ of all drowning by suicide, found in this study, is extremely high. A recent study of suicidal drowning in 32 OECD countries (2012-2014) ranks the Netherlands second-high [58]. Other national study on suicidal drowning report a portion between 7.2 and $31 \%$ [32, 51-53, 59-62]. The incidence of suicide by drowning in all studies is consistently highest in the age groups of 70 years and above $[52,53,56,59$, $63,64]$. Most studies find that women are more likely to commit suicide by drowning than men, although there are significant gender differences between countries and regions [52, 53, 56, 62-66]. Drowning seems also not to be the preferred method of suicide for young people [67]. When comparing between suicides by persons with a native Dutch background and those by persons with a non-western migration background, the suicide rate is statistically higher in the age groups $10-49$ years and non-statistically higher in the age groups 50-59years and 80 years and older. The lower incidence of suicides by non-western inhabitants in the Netherlands has been reported before $[68,69]$. 


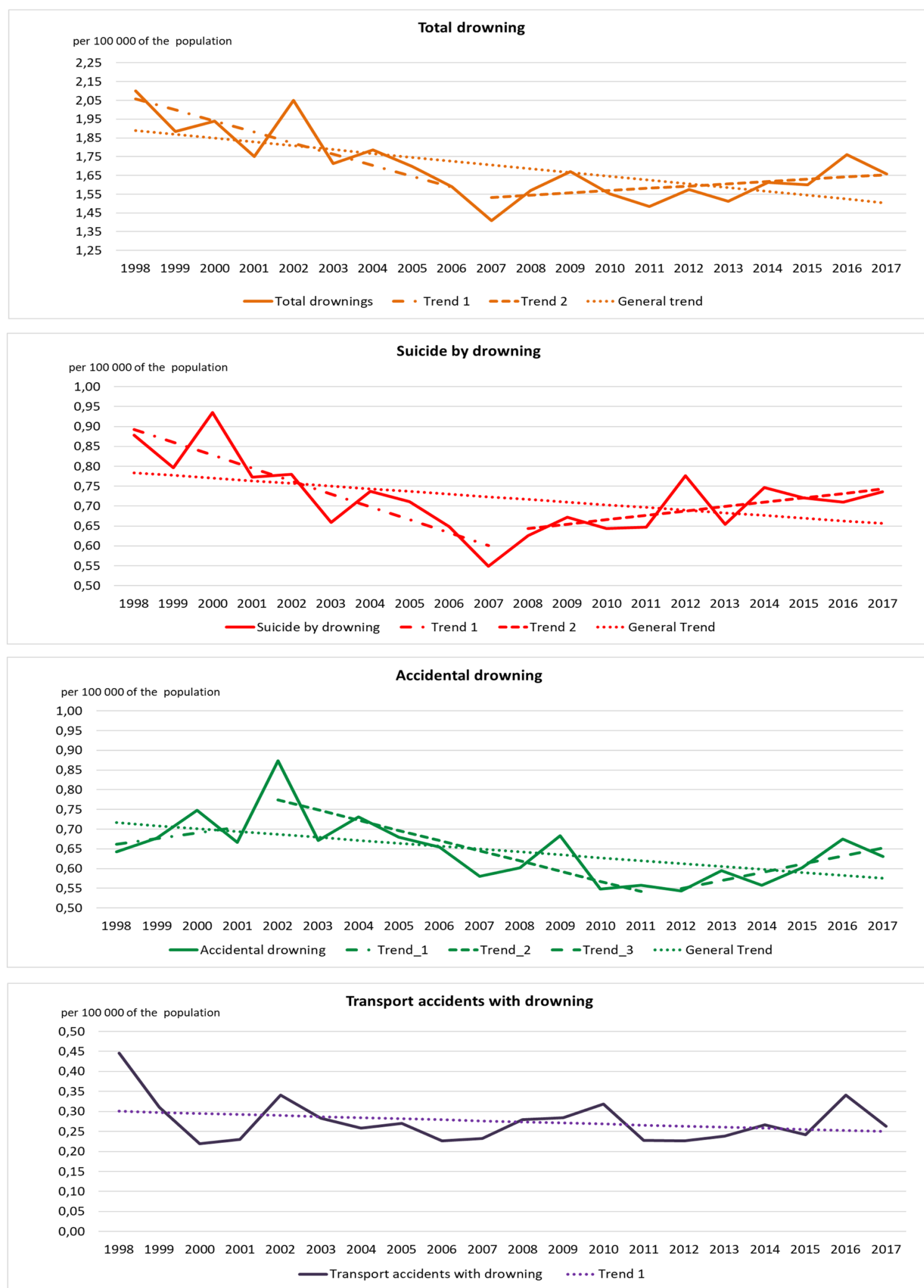

Fig. 4 Trends of fatal drowning in the Netherlands 1998-2017; incidence per 100,000 of the population by cause of drowning; single regression analysis and breakpoint analysis, Additional information of the breakpoint analysis is available in Supplementary Table to Figure 4 
Table 3 Fatal drowning in the Netherlands; comparison between 1998 and 2007 and 2008-2017 by cause of drowning and age group. The mortality ratio of 2008-2017 is age-adjusted (SM) based on the population 1998-2007. Additional information on Standard Mortality, Standard Mortality Ratio, Deviation Rate and $95 \%$ Confidence Interval is available as Supplementary Table 3

\begin{tabular}{lll}
\hline & \multicolumn{1}{l}{$\mathbf{1 9 9 8 - 2 0 0 7}$} & \multicolumn{2}{c}{$\mathbf{2 0 0 8 - 2 0 1 7}$} \\
& \multicolumn{2}{l}{ Standard Mortality (SM) } \\
\hline Total drowning & & \\
Number of drownings & 2886 & 2685 \\
Incidence per 100,000 & 1.79 & 1.60 \\
Standard Mortality & 1.79 & $1.51^{* *}$ \\
Average age at death & $48.9 \mathrm{yrs}$ & $52.8 \mathrm{yrs}$ \\
Male / female & 2.3 & 2.4 \\
Suicide by drowning & & \\
Number of drownings & 1202 & 1164 \\
Incidence per 100,000 & 0.75 & 0.69 \\
Standard Mortality & 0.75 & $0.63^{* *}$ \\
Average age at death & $57.9 \mathrm{yrs}$ & $59.4 \mathrm{yrs}$ \\
Male / female & 1.4 & 1.5 \\
Accidental drowning & & \\
Number of drownings & 1113 & 1004 \\
Incidence per 100,000 & 0.69 & 0.60 \\
Standard Mortality & 0.69 & $0.58^{* *}$ \\
Average age at death & $41.9 \mathrm{yrs}$ & $47.3 \mathrm{yrs}$ \\
Male / female & 3.8 & 3.7 \\
Transport accidents with drowning & & 4.0 \\
Number of drownings & 453 & 0.27 \\
Incidence per 100,000 & 0.28 & $52.8 \mathrm{yrs}$ \\
Standard Mortality & 0.28 & 4.0 \\
Average age at death & $48.9 \mathrm{yrs}$ \\
Male / female & 3.7 & \\
\hline
\end{tabular}

** Standard Mortality (SM) in the period 2008-2017 is significantly lower compared to $1998-2007$ (t-test: $p<0.05)$

Of all suicides in the Netherlands, approximately $7.0 \%$ is by drowning [62]. In a database that includes 160,460 suicides in 16 European countries over a 5 -years period, drowning accounted for $3 \%$ of all male and $7.8 \%$ of all female suicides; the highest percentage was $25.5 \%$ in Irish women and the lowest percentage was $0.3 \%$ for Estonian men [63]. Several other non-European studies [54, 56, 59, 64] and one systematic review [62] also show that of all suicide methods, drowning constitutes a small portion. Several recent studies have detected a decreasing trend in drowning by suicide $[54,62,64]$.

A number of studies have tried to explain the differences in suicide by drowning between countries by length of coastline or shoreline, distance to water, "blue spaces" (visible bodies of fresh and salt water), and culturally
Table 4 Fatal drowning in the Netherlands; comparison between 1998 and 2007 and 2008-2017 by migration background. The incidence of 2008-2017 is age-adjusted (Standard Mortality) based on the population 1998-2007 of the group with the same background. Additional information on Standard Mortality, Standard Mortality Ratio, Deviation Rate and 95\% Confidence Interval by cause of drowning and migration background is available as Supplementary Table 4

\begin{tabular}{|c|c|c|}
\hline & $1998-2007$ & 2008-2017 \\
\hline & \multicolumn{2}{|c|}{ Standard Mortality (SM) } \\
\hline \multicolumn{3}{|l|}{ Total drownings } \\
\hline Native Dutch background & 1.55 & $1.25^{* *}$ \\
\hline Western background & 1.50 & 1.34 \\
\hline Non-western background & 1.99 & $1.54^{*}$ \\
\hline \multicolumn{3}{|l|}{ Suicide by drowning } \\
\hline Native Dutch background & 0.71 & $0.59^{* *}$ \\
\hline Western background & 0.65 & 0.56 \\
\hline Non-western background & 0.60 & $0.50^{* *}$ \\
\hline \multicolumn{3}{|l|}{ Accidental drowning } \\
\hline Native Dutch background & 0.52 & $0.41^{* *}$ \\
\hline Western background & 0.57 & 0.52 \\
\hline Non-western background & 1.00 & $0.75^{* *}$ \\
\hline \multicolumn{3}{|c|}{ Transport accidents with drowning } \\
\hline Native Dutch background & 0.26 & $0.22^{* *}$ \\
\hline Western background & 0.19 & 0.22 \\
\hline Non-western background & 0.28 & $0.21^{* *}$ \\
\hline
\end{tabular}

** Standard mortality (SM) in the period 2008-2017 is significantly lower compared to 1998-2007 (t-test: $p<0.05$ )

influenced gender-specific self-destructive behaviour [63, 70-72]. In none of the studies, a correlation could be detected. A more likely explanation of the large proportion of drowning by suicide in the Netherlands might be the omnipresent accessibility to water, the lack of access to other means such as firearms, railway suicide prevention programmes and the robust regulations for the prescription of medications [73, 74].

\section{Accidental drowning}

This study confirms a recently described observation in studies from high-income countries, observing that the traditionally highest incidence of accidental drowning in the $0-9$ years old group is gradually replaced by the highest incidence in the age categories above 50 years of age [2, 26, 75], including South Africa [76], Canada [77], Sweden [61, 78] and China [24]. There may be several reasons for this change, including more leisure time and exposure to water for those who are still fit and healthy at this age, or on the other end, weaker health and condition that causes a minor incident to have a fatal outcome. In all accidental drowning studies, the majority of the victims 


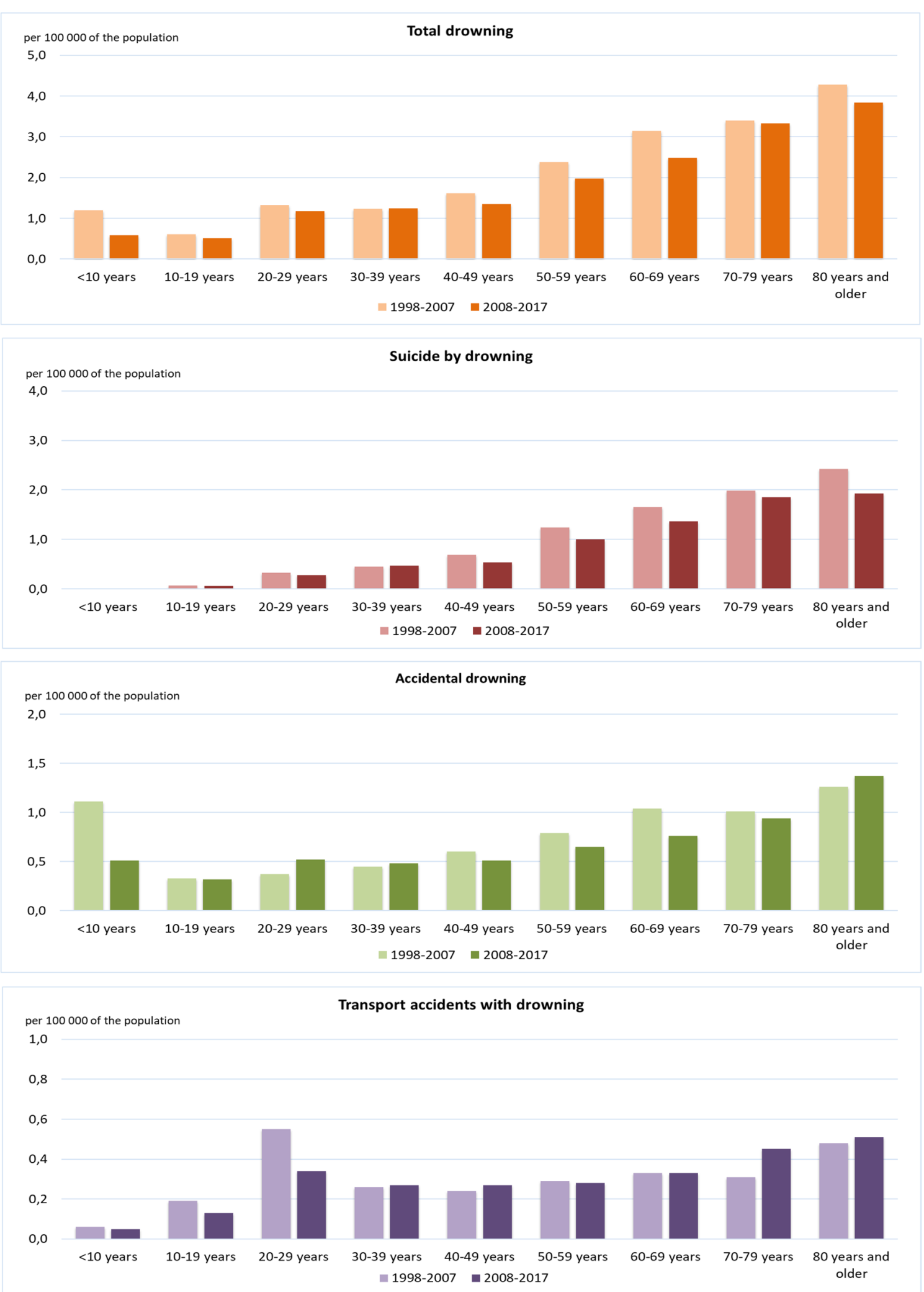

Fig. 5 Fatal drowning in the Netherlands, comparison between 1998 and 2007 and 2008-2017: by cause of drowning and age group. Additional information on Standard Mortality, Standard Mortality Ratio, and 95\% Confidence Interval is available in Supplementary Table 3 
are male, although the male: female ratio may vary a lot between countries, ages, and locations [23, 26, 76, 79, 80]. Some studies showed relative higher rates of accidental female drowning in bathtubs [8] or in female indigenous people [46].

\section{Transportation}

It should not come as a surprise that transportation drowning is common in a country with high population density and abundant waterways often immediately next to roads $(330,000 \mathrm{~km}$ of ditches, $6500 \mathrm{~km}$ of canals, $6200 \mathrm{~km}$ of streams and $650 \mathrm{~km}$ of rivers) [81]. In this study, land and water transportation accidents have been combined and result in $16.2 \%$ of all drowning deaths. A few other studies on transportation drowning describe that between 5.6 and $15.8 \%$ of all fatal drowning is related to transportation $[53,77,82,83]$. Because drowning during transport is often coded as transportation death and not as drowning death, other sources than ICD codes had to be used to understand the incidence of transportation drowning $[5,84]$. The causes vary and include recreational boating [85, 86], fishing [87-89], public transport by water [84, 88], high speed crafts [90], cruise ships [91] as well as snow mobiles [23, 92, 93], submerged cars [94-97], and cars trapped in floods [26, 98]. The Dutch Institute for Road Safety Research (Stichting Wetenschappelijk Onderzoek Verkeersveiligheid: SWOV) reports traffic accidents, including traffic accidents that end in water. Unfortunately, the data are almost all based on police reports and do not allow an overall picture of the total number of transport accidents that result in fatal drowning [99-101].

\section{Ethnicity and non-residents}

Another significant observation from this study, and reported previously [102, 103], is that a significant portion $(41 \%)$ of all accidental drowning in the Netherlands concern inhabitants with a western migration background (8\%), a non-western migration background (14\%), and non-residents (19\%). The SM of persons with a nonwestern migration background is almost twice as high as among persons with a western migration background or native Dutch background (2.70 vs 1.44 and 1.46 resp. per 100,000). It can be assumed that many of them are not yet familiar with the omni-presence of water and the typical characteristics such as low temperature, current, and bottom profiles. In addition, peer pressure (children with a migration background with lower swimming skills follow friends with a Dutch background with better swimming skills in risky behaviour) seems a relevant factor [104-106]. The incidence of accidental drowning among persons with a western background is the same as for persons with a native Dutch background (0.5 and 0.6 resp. per 100,000). These incidence figures of accidental drowning are in line with the incidence of drowning mortality in the western part of Europe, northern American countries and Australia [20, 22, 107-110]. On the other hand, the incidence of accidental drowning for Dutch inhabitants with a non-Western background is significantly higher (1.2 per 100,000); this comes close to international statistics of non-Western countries [2]. It is not possible to calculate the incidence of drowning of people who are not registered in the Netherlands. The total number of accidental drowning fatalities is higher among non-residents $(n=399)$ than among non-western residents $(n=298)$. The difference in the total number is smaller due to fewer suicides (679 vs 625). Non-residents are often ignored in national drowning statistics and when included, often reported by countries and islands where the beaches and pools are populated by tourists $[15,19,111-115]$. Some data on non-residential drowning can be extracted from annual national lifesaving reports [116, 117]. Non-residents who drown in the Netherlands are often foreign workers, asylum seekers and, for example, tourists who drown in canals after a visit to a bar [118].

\section{Trends}

SM and SMR in the first decade (1998-2007) compared to the second decade (2008-2017), as well as decreasing trend when a single regression analysis was applied over the period 1998-2017, show a decline regarding all causes, most age groups and residents with native Dutch and non-western backgrounds. The reduction of accidental drowning numbers in the Netherlands would have been well in line with statistics from most high-income countries around the world, where a consistent and on-going decreasing trend can be observed. This includes significant decreases in 9-14years old children in Europe between 1990 and 2016: a total decrease of $64.4 \%$ and in children aged 5-9years of 72\% [22]. Similar findings are reported in 33 European countries [119], and Australia [120]. The decrease, with rates that vary between 5 and $80 \%$, is also reported in studies initiated in low and middle-income countries or based on the Global Burden of Disease registrations (GBD) [2, 24, 38, 77, 121-124]. This decreasing trend in accidental drowning is speculatively explained by better socioeconomic situations, improved infrastructure planning such as piped water supply resulting in less frequent and less easy access to water, mandatory education, safer swimming and bathing facilities, aquatic safety education and swimming lessons [10, 22, 24, 125-127). Notably more urbanisation is hypothesised to be a major factor, as this decreases the access to open water, causes 
shifts towards indoor activities and entertainment and reduces income differences $[2,24,28]$. A decreasing trend in drowning by suicide had also been reported $[66,128]$.

In addition to the comparison between two periods and a single regression analysis, also a breakpoint analysis has been performed. This resulted in the remarkable observation that, within the decreasing trend over the full period under investigation, there is an upward trend in the total number of drowning after 2007, in suicidal drowning after 2009 and in accidental drowning after 2012. These recent upward trends were missed in the trend analysis over the full period and contradict the general impression that the incidence of drowning in the Netherlands is stable or decreasing. There is no explanation for this observation at this moment.

\section{Limitations}

This study has certain limitations. First of all, the focus of data reporting and analysis is on a small selection of demographic data. The inclusion of more details may have provided different clues for a better understanding of the national burden of drowning such as body of water, mechanism of drowning, and geographic, seasonal and economic data [121]. These data are available and may be reported in the future. Also, data on non-fatal drowning victims recorded by aquatic rescue organisations and patients admitted to emergency departments and intensive care units will enhance the perspective on the issue $[3,46$, 129-131]. Although categorisation systems for clinical studies are available which report fatal and non-fatal drowning data in a standardised way, these systems are not suitable for demographic or epidemiological studies $[4,127,132,133]$.

Very likely, not all Dutch persons who drowned outside the Netherlands have been included or may have been included with less accurate data.

It may have been interesting to compare the data on age and migration background before and after the various breakpoints for each group of drowning. For reasons of consistent reporting and to avoid an overload of data, we have compared two equal periods (1998-2007 vs 2008-2017). Seasonal effect, net drift, local drift [24], piecewise analysis or joint point trend analysis could have been included to further explore if any other trend could be detected.

It was decided to not include such information because the results of these analyses would substantially increase the length of the paper and distract from the objective of this study.

\section{Conclusion}

Reporting on the total drowning burden is a muchneeded area of study with underreported gaps in the literature. This paper addresses these gaps and provides detailed analysis based on an inclusive dataset. The actual incidence of fatal drowning found in this study is $350 \%$ higher than the public available number of drowning. $39.1 \%$ of the drownings are accidental drowning by residents, which in general is considered the official drowning estimate in the presentation of national drowning statistics. Drowning by suicide and drowning by persons over the age of 50 are leading in the drowning statistics of the Netherlands, $12.2 \%$ are non-residents. Although the total number of drowning remains more or less the same, the incidence of drowning and comparing 1989-2007 with 2008-2017, show a decreasing trend over a period of 20 year. An additional breakpoint analysis however observed several recent upwards trends.

The study emphasises once again that national drowning statistics, comparisons between national drowning statistics based on accidental drowning, and trend analysis need to be interpreted cautiously. Countries may have different proportions of drowning by suicide, accidental, transport and disasters and therefore the proportion of victims not included in statistics of accidental drowning. In-depth studies, knowledgeable trend analysis and looking beyond routinely collected and reported data are required to accurately investigate the burden of drowning and to understand the large variety in the numbers of deaths by drowning among countries. This study underlines the importance of recently (April 2021) passed United Nation resolution on drowning that advises "to aggregate all drowning mortality data into national estimates" as one of the actions to address this largely underrecognised public health problem [134].

\section{Supplementary Information}

The online version contains supplementary material available at https://doi. org/10.1186/s12889-022-12620-3.

Additional file 1. Supplementary Table to Figure 1 and Table 1. Fatal drowning in the Netherlands 1998-2017; total number and incidence per 100,000 of the population by cause of drowning and age group. Supplementary Table to Figure 1a. Total number of fatal drowning in the Netherlands 1998-2017; by cause of drowning and age group. Supplementary Table to Figure 1b. Incidence per 100,000 of the population of fatal drowning in the Netherlands 1998-2017; by cause of drowning and age group.

Additional file 2. Supplementary Table to Figure 2 and Table 2. Fatal drowning in the Netherlands 1998-2017: Comparison between migration backgrounds and non-residents. Additional information on Standard Mortality, Standard Mortality Ratio, Deviation Rate and 95\% Confidence Interval by cause of drowning, migration background and age group.

Additional file 3. Supplementary Table to Figure 3. Trend of fatal drowning in the Netherlands 1998-2017; by cause of drowning: trend of total number and of incidence per 100,000 of the population by year and cause of drowning.

Additional file 4. Supplementary Table to Figure 4. Trends of fatal drowning in the Netherlands 1998-2017; incidence per 100,000 of the population by cause of drowning; single regression analysis and breakpoint analysis. Additional information of the breakpoint analysis. 
Additional file 5. Supplementary Table 3. Fatal drowning in the Netherlands 1998-2017; comparison between 1998 and 2007 and 2008-2017 by cause of drowning and age group. The mortality ratio of 2008-2017 is age-adjusted (SM) based on the population 1998-2007. Additional information on Standard Mortality, Standard Mortality Ratio, Deviation Rate and 95\% Confidence Interval.

Additional file 6. Supplementary Table 4. Fatal drowning in the Netherlands 1998-2017; comparison between 1998 and 2007 and 2008-2017; Additional information on Standard Mortality, Standard Mortality Ratio, Deviation Rate and 95\% Confidence Interval by cause of drowning and migration background.

\section{Acknowledgements}

The authors acknowledge Bob Lodder, Statistics Netherlands (CBS), Research and Development, Department of Methodology for his support regarding the trend-analysis.

\section{Authors' contributions}

$\mathrm{JB}$ and $\mathrm{JH}$ designed the study, JH performed the collection of data, $\mathrm{JB}$ and $\mathrm{JH}$ analysed the data and wrote the manuscript. All authors contributed to the study conception and design. Material preparation, data collection and analysis were performed by both authors. The first draft of the manuscript was written by $\mathrm{JB}$ and $\mathrm{JH}$ commented on previous versions of the manuscript. Both authors read and approved the final manuscript.

\section{Funding}

Not applicable. No funding was received for conducting this study.

\section{Availability of data and materials}

By law, information from individual records is not allowed to leave the offices of the CBS as this may result in the identification of individual persons. For this reason, the original datasets generated and analysed during the current study are not publicly available. The public available data sets are available at. https://www.cbs.nl/en-gb/our-services/methods/definitions and https:// www.cbs.nl/en-gb/our-services/methods/surveys/korte-onderzoeksbeschrijvi ngen/causes-of-death-statistics

Tables and figures that are at the basis of the current manuscript are available from the corresponding author on reasonable request.

\section{Declarations}

\section{Ethics approval and consent to participate}

This national study is a secondary analysis involving no identifiable patient data and no ethical restraints were applicable. For the same reason no consent to participate was required or possible. All methods in the study were carried out in accordance with the Helsinki guidelines and declaration or any other relevant guidelines.

\section{Consent for publication}

Not applicable. The publication has been approved by Statistics Netherlands (CBS) where the data collection has been carried out.

\section{Competing interests}

The authors have no relevant financial or non-financial interests of competing interests to disclose.

\section{Author details}

${ }^{1}$ Research Group Emergency and Disaster Medicine, Vrije Universiteit Brussels, Laarbeeklaan 103, 1090 Brussels, Belgium. ${ }^{2}$ Centraal Bureau voor de Statistiek (Statistics Netherlands), Department of Causes of Death Statistics, Henri Faasdreef 312, 2492, JP, Den Haag, the Netherlands.

Received: 9 August 2021 Accepted: 14 January 2022

Published online: 17 February 2022

\section{References}

1. World Health Organization. Global report on drowning: preventing a leading killer. Geneva: World Health Organization; 2014. Available at: https://apps.who.int/iris/handle/10665/143893. Accessed 2 Feb 2022.

2. Franklin RC, Peden AE, Hamilton EB, Bisignano C, Castle CD, Dingels $Z V$, et al. The burden of unintentional drowning: global, regional and national estimates of mortality from the Global Burden of Disease 2017 Study. Inj Prev. 2020;26(Supp 1):i83-95. https://doi.org/10.1136/injur yprev-2019-043484 Epub 2020 Feb 20. Erratum in: Inj Prev. 2020 Sep 28;: PMID: 32079663; PMCID: PMC7571364.

3. Bierens JJLM, Stiphout WAHJ. The use of LMR data for analysis of clinical enquiry. In: Bierens JJLM. Drowning in the Netherlands: pathophysiology, epidemiology and clinical studies: PhD-thesis. Utrecht: University of Utrecht; 1996. p. 66-78.

4. Smith GS and the WET ICE collaborative group. International mortality databases: evaluation of their usefulness for drowning prevention and surveillance (year unknown). Available at: https://www.cdc.gov/nchs/ data/ice/ice95v2/c06.pdf (accessed: Aug $8^{\text {th }}$ 2021).

5. Smith GS, Langley JD. Drowning surveillance: how well do E codes identify submersion fatalities. Inj Prev. 1998;4(2):135-9. https://doi.org/ 10.1136/ip.4.2.135.

6. Langley JD, Warner M, Smith GS, Wright C. Drowning-related deaths in New Zealand, 1980-94. Aust N Z J Public Health. 2001;25(5):451-7.

7. Miller L, Alele FO, Emeto TI, Franklin RC. Epidemiology, risk factors and measures for preventing drowning in Africa: a systematic review. Medicina (Kaunas). 2019;55(10):637. https://doi.org/10.3390/medic ina55100637 Published 2019 Sep 25.

8. Henderson $\mathrm{H}$, Wilson RC. Water incident related hospital activity across England between 1997/8 and 2003/4: a retrospective descriptive study. BMC Public Health. 2006;6:210. https://doi.org/10.1186/1471-2458-6210 Published 2006 Aug 16.

9. Lin CY, Wang YF, Lu TH, Kawach I. Unintentional drowning mortality, by age and body of water: an analysis of 60 countries. Inj Prev. 2015;21(e1):e43-50. https://doi.org/10.1136/injuryprev-2013-041110.

10. Lin CY, Wang LY, Lu TH. Changes in drowning mortality rates and quality of reporting from 2004-2005 to 2014-2015: a comparative study of 61 countries. BMC Public Health. 2019;19(1):1391. https://doi.org/10.1186/ s12889-019-7749-2 Published 2019 Oct 28.

11. Jonkman SN, Kelman I. An analysis of the causes and circumstances of flood disaster deaths. Disasters. 2005;29(1):75-97. https://doi.org/10. 1111/j.0361-3666.2005.00275.x.

12. Bern C, Sniezek J, Mathbor GM, et al. Risk factors for mortality in the Bangladesh cyclone of 1991. Bull World Health Organ. 1993;71(1):73-8.

13. Doocy S, Daniels A, Dick A, Kirsch TD. The human impact of tsunamis: a historical review of events 1900-2009 and systematic literature review. PLoS Curr. 2013;5:ecurrents.dis.40f3c5cf61110a0fef2f9a2590 8cd795. https://doi.org/10.1371/currents.dis.40f3c5cf61110a0fef2f 9a25908cd795 Published 2013 Apr 16.

14. Martinez RE, Go JJ, Guevarra J. Epidemiology of drowning deaths in the Philippines, 1980 to 2011. Western Pac Surveill response J. 2016;7(4):1-5 Published 2016 Nov 8. https://doi.org/10.5365/WPSAR. 2016.7.2.005

15. Lazicić-Putnik L, Rac OD, Lazarić-Zec D. Causes of death of foreign tourists in the county of Istria during the summer holiday season from 2000 to 2004. Int Marit Health. 2005;56(1-4):129-34.

16. Morgan D, Ozanne-Smith J, Triggs T. Descriptive epidemiology of drowning deaths in a surf beach swimmer and surfer population. Inj Prev. 2008;14(1):62-5. https://doi.org/10.1136/ip.2006.013508.

17. Lunetta P. Injury deaths among finnish residents travelling abroad. Int J Inj Control Saf Promot. 2010;17(3):161-8. https://doi.org/10.1080/17457 300903453112

18. Galvin S, Robertson R, Hargarten S. Injuries occurring in medical students during international medical rotations: a strategy toward maximizing safety. Fam Med. 2012;44(6):404-7.

19. Barnsley PD, Peden AE, Scarr J. Calculating the economic burden of fatal drowning in Australia. J Saf Res. 2018;67:57-63. https://doi.org/10. 1016/j.jsr.2018.09.002.

20. Peden AE, Franklin RC, Clemens T. Exploring the burden of fatal drowning and data characteristics in three high income countries: Australia, 
Canada and New Zealand. BMC Public Health. 2019;19(1):794. https:// doi.org/10.1186/s12889-019-7152-z Published 2019 Jun 21.

21. Hu G, Mamady K. Impact of changes in specificity of data recording on cause-specific injury mortality in the United States, 1999-2010. BMC Public Health. 2014;14:1010. https://doi.org/10.1186/1471-2458-141010 Published 2014 Sep 27.

22. Kyu HH, Stein CE, Boschi Pinto C, et al. Causes of death among children aged 5-14 years in the WHO European region: a systematic analysis for the global burden of disease study 2016. Lancet Child Adolesc Health. 2018;2(5):321-37. https://doi.org/10.1016/\$2352-4642(18)30095-6.

23. Lunetta P, Penttilä A, Sajantila A. Drowning in Finland: "external cause" and "injury" codes. Inj Prev. 2002;8(4):342-4. https://doi.org/10.1136/ ip.8.4.342.

24. Wang Z, Yu C, Xiang H, Li G, Hu S, Tang J. Age-period-cohort analysis of trends in mortality from drowning in China: data from the global burden of disease study 2015. Sci Rep. 2018;8(1):5829. https://doi.org/ 10.1038/s41598-018-24281-7 Published 2018 Apr 11.

25. Peden MM, McGee K. The epidemiology of drowning worldwide. Inj Control Saf Promot. 2003;10(4):195-9. https://doi.org/10.1076/icsp.10.4. 195.16772.

26. Peden AE, Franklin RC, Mahony AJ, Scarr J, Barnsley PD. Using a retrospective cross-sectional study to analyse unintentional fatal drowning in Australia: ICD-10 coding-based methodologies verses actual deaths. BMJ Open. 2017;7(12):e019407. https://doi.org/10.1136/bmjopen-2017019407 Published 2017 Dec 21.

27. Peden AE, Mahony AJ, Barnsley PD, Scarr J. Understanding the full burden of drowning: a retrospective, cross-sectional analysis of fatal and non-fatal drowning in Australia. BMJ Open. 2018;8(11):e024868. https:// doi.org/10.1136/bmjopen-2018-024868 Published 2018 Nov 24

28. Peden AE, Franklin RC. Exploring the impact of remoteness and socioeconomic status on child and adolescent injury-related mortality in Australia. Children. 2021;8:5.

29. Wise PH, Darmstadt GL. The grand divergence in global child health: confronting data requirements in areas of conflict and chronic political instability. JAMA Pediatr. 2016;170(3):195-7. https://doi.org/10.1001/ jamapediatrics.2015.4275 PMID: 26809944.

30. World Health Organisation, Global Health Estimates 2019. Available at: https://www.who.int/data/gho/data/themes/mortality-and-globalhealth-estimates/ghe-leading-causes-of-death. Accessed Jul $9^{\text {th }} 2021$.

31. Lunetta P, Smith GS, Penttila A, Sajantila A. Undetermined drowning. Med Sci Law. 2003;43(3):207-14. https://doi.org/10.1258/rsmmsl.43.3. 207.

32. Lunetta P, Smith GS, Penttilä A, Sajantila A. Unintentional drowning in Finland 1970-2000: a population-based study. Int J Epidemiol. 2004;33(5):1053-63. https://doi.org/10.1093/ije/dyh194.

33. Lu TH, Lunetta P, Walker S. Quality of cause-of-death reporting using ICD-10 drowning codes: a descriptive study of 69 countries. BMC Med Res Methodol. 2010;10:30. https://doi.org/10.1186/1471-2288-10-30 Published 2010 Apr 8.

34. Statistics Netherlands. Methodology causes of death statistics. Available at: https://www.cbs.nl/en-gb/our-services/methods/surveys/korteonderzoeksbeschrijvingen/causes-of-death-statistics Accessed Aug 9th 2021.

35. Statistics Netherlands. Annual report on integration 2016. Available at: https://www.cbs.nl/en-gb/publication/2016/47/annual-report-on-integ ration-2016). Accessed Aug 9th 2021.

36. Statistics Netherlands. Statline. Regionale kerncijfers Nederland (regional core data). Available at: https://opendata.cbs.nl/statline/\#/ CBS/nl/dataset/70072ned/table?dl=3FDFE. Accessed Aug 9th 2021

37. Statistics Netherlands. Statline. Overleden door verdrinkingen (death by drowning). Available at: https://opendata.cbs.nl/\#/CBS/nl/dataset/ 7052_95/table?ts=1611918552556 Accessed Aug 9h 2021.

38. Wu Y, Huang Y, Schwebel DC, Hu G. Unintentional child and adolescent drowning mortality from 2000 to 2013 in 21 countries: analysis of the WHO mortality database. Int J Environ Res Public Health. 2017;14(8):875. https://doi.org/10.3390/ijerph14080875 Published 2017 Aug 4.

39. Bierens J, Knape J. The world congress on drownin 2002: a move towards the future. In JJLM Bierens, editor. Drowning: prevention, rescue, treatment, vol. 2014. Heidelberg: Springer Verlag Heidelberg; p. $45-61$.
40. Krug E. Injury. A leading cause of the global burden of disease. Geneva: WHO; 1999. Available at: https://apps.who.int/iris/handle/10665/66160. Accessed Aug $9^{\text {th }} 2021$

41. UNICEF/TASC. Towards a world safer for children. Proceedings of UNICEF/TASC Conference on Child Injury. Bangkok: UNICEF/TASC; 2004.

42. Peden M, Oyegbite K, Ozanne-Smith J, Hyder AA, Branche C, Rahman AKMF, et al. Bartolomeos. World report on injury prevention: WHO, UNICEF; 2014. p. 59-78. Available at: https://apps.who.int/iris/bitstream/ handle/10665/43851/9789241563574_eng.pdfijsessionid =44BC593E52 D5FC2D44A92FBE42AB2AAB? sequence $=1$. Accessed Aug $9^{\text {th }} 2021$

43. Linnan M, Rahman A, Scarr J, Reinten-Reynolds T, Linnan H, Rui-Wei J, et al. Child drowning: evidence for a newly recognized cause of child mortality in low and middle income countries in Asia', working paper 2012-07, special series on child injury no. 2. Florence: UNICEF Office of Research. https://www.unicef-irc.org/publications/pdf/drowning.pdf

44. Vignac E, Lebihain P, Soulé B. Tracking fatal drownings in swimming pools: a retrospective multiscale investigation within France. IJARE. 2015;9:184-200.

45. Bierens JJLM, Stiphout WAHJ, Swenne-van Ingen MME, Knape JTA. 2944 submersion victims: an analysis of external causes, concommitant risk factors, complications and prognosis. In: JJLM B, editor. Drowning in the Netherlands: pathophysiology, epidemiology and clinical studies: PhDthesis. Utrecht: University of Utrecht; 1996. p. 82-100.

46. Wallis BA, Watt $K$, Franklin RC, Kimble RM. Drowning in aboriginal and torres strait islander children and adolescents in Queensland (Australia). BMC Public Health. 2015;15:795. Published 2015 Aug 19. https://doi. org/10.1186/s12889-015-2137-z.

47. Wallis BA, Watt K, Franklin RC, Nixon JW, Kimble RM. Drowning mortality and morbidity rates in children and adolescents 0-19yrs: a populationbased study in Queensland. Australia PLoS One. 2015;10(2):e0117948. Published 2015 Feb 25. https://doi.org/10.1371/journal.pone.0117948.

48. Sarrassat S, Mrema S, Tani K, Mecrow T, Ryan D, Cousens S. Estimating drowning mortality in Tanzania: a systematic review and meta-analysis of existing data sources. Inj Prev. 2019;25(5):459-71. https://doi.org/10. 1136/injuryprev-2018-042939.

49. Murray K, Carter P. Fatal Drownings in Fiji. Asia Pac J Public Health. 2017;29(1):28-34. https://doi.org/10.1177/1010539516685610.

50. Kiakalayeh AD, Mohammadi R, Stark Ekman D, Yousefzade-Chabok S, Behboudi $F$, Jansson B. Estimating drowning deaths in northern Iran using capture-recapture method. Health Policy. 2011;100(2-3):290-6. https://doi.org/10.1016/j.healthpol.2010.09.005 Epub 2010 Oct 15. PMID: 20951461

51. Capková M, Velemínský M, Benesová V, Grivna M. Monitoring of drowning and near-drowning in the Czech Republic in the years 2001-2002. Int J Inj Control Saf Promot. 2006;13(1):43-5. https://doi.org/10.1080/ 17457300500089152 PMID: 16537223.

52. Cenderadewi M, Franklin RC, Peden AE, Devine S. Pattern of intentional drowning mortality: a total population retrospective cohort study in Australia, 2006-2014. BMC Public Health. 2019;19(1):207 Published 2019 Feb 19. https://doi.org/10.1186/s12889-019-6476-z.

53. Cenderadewi M, Franklin RC, Peden AE, Devine S. Fatal intentional drowning in Australia: a systematic literature review of rates and risk factors. PLoS One. 2020;15(5):e0231861. https://doi.org/10.1371/journal. pone.0231861 PMID: 32442177 ; PMCID: PMC7244177.

54. Salib E. Trends in suicide by drowning in the elderly in England and wales 1979-2001. Int J Geriatr Psychiatry. 2005;20(2):175-81. https://doi. org/10.1002/gps.1211.

55. Connolly JF, Cullen A. Under-reporting of suicide in an Irish county. Crisis. 1995;16(1):34-8. https://doi.org/10.1027/0227-5910.16.1.34.

56. Byard RW, Houldsworth G, James RA, Gilbert JD. Characteristic features of suicidal drownings: a 20-year study. Am J Forensic Med Pathol. 2001;22(2):134-8. https://doi.org/10.1097/00000433-200106000-00005.

57. Tøllefsen IM, Thiblin I, Helweg-Larsen K, et al. Accidents and undetermined deaths: re-evaluation of nationwide samples from the scandinavian countries. BMC Public Health. 2016;16:449. Published 2016 May 27. https://doi.org/10.1186/s12889-016-3135-5.

58. Hsieh WH, Wang CH, LuTH. Drowning mortality by intent: a populationbased cross-sectional study of 32 OECD countries, 2012-2014. BMJ Open. 2018;8(7):e021501 Published 2018 Jul 23. https://doi.org/10. 1136/bmjopen-2018-021501. 
59. Wirthwein DP, Barnard JJ, Prahlow JA. Suicide by drowning: a 20-year review. J Forensic Sci. 2002;47(1):131-6 PMID: 12064640.

60. Stemberga V, Bralic M, Coklo M, Cuculic D, Bosnar A. Suicidal drowning in southwestern Croatia: a 25-year review. Am J Forensic Med Pathol. 2010;31(1):52-4. https://doi.org/10.1097/PAF.0b013e3181c215c8.

61. Ahlm K, Saveman Bl, Björnstig U. Drowning deaths in Sweden with emphasis on the presence of alcohol and drugs - a retrospective study, 1992-2009. BMC Public Health. 2013;13:216. Published 2013 Mar 11. https://doi.org/10.1186/1471-2458-13-216.

62. Haw C, Hawton K. Suicide and self-harm by drowning: a review of the literature. Arch Suicide Res. 2016;20(2):95-112. https://doi.org/10.1080/ 13811118.2015.1025120.

63. Värnik A, Kölves K, van der Feltz-Cornelis CM, et al. Suicide methods in Europe: a gender-specific analysis of countries participating in the "European Alliance against depression". J Epidemiol Community Health. 2008;62(6):545-51. https://doi.org/10.1136/jech.2007.065391.

64. Large MM, Nielssen OB. Suicide in Australia: meta-analysis of rates and methods of suicide between 1988 and 2007. Med J Aust. 2010;192(8):432-7.

65. Rockett IR, Smith GS. Covert suicide among elderly Japanese females: questioning unintentional drownings. Soc Sci Med. 1993;36(11):146772. https://doi.org/10.1016/0277-9536(93)90388-k.

66. Wu Y, Schwebel DC, Huang Y, Ning P, Cheng P, Hu G. Sex-specific and age-specific suicide mortality by method in 58 countries between 2000 and 2015. Inj Prev. 2021;27(1):61-70. https://doi.org/10.1136/injuryprev2019-043601 Epub 2020 Mar 8. PMID: 32152194; PMCID: PMC7848049.

67. Berkelmans G, van der Mei R, Bhulai S, Merelle S, Gilissen R. Demographic risk factors for suicide among youths in the Netherlands. Int J Environ Res Public Health. 2020;17(4):1182. Published 2020 Feb 13. https://doi.org/10.3390/ijerph17041182.

68. Stirbu I, Kunst AE, Bos V, van Beeck EF. Injury mortality among ethnic minority groups in the Netherlands. J Epidemiol Community Health. 2006;60(3):249-55. https://doi.org/10.1136/jech.2005.037325.

69. Garssen MJ, Hoogenboezem J. Zelfdoding in Nederland: een statistisch overzicht. Bevolkingstrends $4^{e}$ kwartaal 2007. CBS Den Haag. 2007:73-83.

70. Moens GF, Loysch MJ, van de Voorde H. The geographical pattern of methods of suicide in Belgium: implications for prevention. Acta Psychiatr Scand. 1988;77(3):320-7. https://doi.org/10.1111/j.1600-0447.1988. tb05128.x.

71. Lester D. The suicide rate by drowning and the presence of oceans. Percept Mot Skills. 1989;69(1):338. https://doi.org/10.2466/pms.1989. 69.1.338.

72. Helbich M, de Beurs D, Kwan MP, O'Connor RC, Groenewegen PP. Natural environments and suicide mortality in the Netherlands: a crosssectional, ecological study. Lancet Planet Health. 2018;2(3):e134-9. https://doi.org/10.1016/S2542-5196(18)30033-0.

73. Swanson SA, Eyllon M, Sheu YH, Miller M. Firearm access and adolescent suicide risk: toward a clearer understanding of effect size. Inj Prev. 2020;27(3):264-70. https://doi.org/10.1136/injuryprev-2019-043605 Epub ahead of print. PMID: 32409621; PMCID: PMC8165151.

74. Ajdacic-Gross V, Weiss MG, Ring M, Hepp U, Bopp M, Gutzwiller F, Rössler W. Methods of suicide: international suicide patterns derived from the WHO mortality database. Bull World Health Organ. 2008:86(9):726-32. https://doi.org/10.2471/blt.07.043489.

75. Peden AE, Franklin RC, Queiroga AC. Epidemiology, risk factors and strategies for the prevention of global unintentional fatal drowning in people aged 50 years and older: a systematic review. Inj Prev. 2018;24(3):240-7. https://doi.org/10.1136/injuryprev-2017-042351.

76. Saunders CJ, Adriaanse R, Simons A, van Niekerk A. Fatal drowning in the Western cape, South Africa: a 7-year retrospective, epidemiological study. Inj Prev. 2019;25(6):529-34. https://doi.org/10.1136/injur yprev-2018-042945

77. Clemens T, Tamim H, Rotondi M, Macpherson AK. A population based study of drowning in Canada. BMC Public Health. 2016;16:559. Published 2016 Jul 13. https://doi.org/10.1186/s12889-016-3221-8.

78. Ahlm K, Lindqvist P, Saveman BI, Björnstig U. Suicidal drowning deaths in northern Sweden 1992-2009 - the role of mental disorder and intoxication. J Forensic Legal Med. 2015;34:168-72. https://doi.org/10.1016/j. jflm.2015.06.002.
79. Howland J, Hingson R, Mangione TW, Bell N, Bak S. Why are most drowning victims men? Sex differences in aquatic skills and behaviors. Am J Public Health. 1996;86(1):93-6. https://doi.org/10.2105/ajph.86.1. 93.

80. Simons A, Govender R, Saunders CJ, Singh-Adriaanse R, Van Niekerk A. Childhood vulnerability to drowning in the Western cape, South Africa: risk differences across age and sex. Child Care Health Dev. 2020;46(5):607-16. https://doi.org/10.1111/cch.12786 Epub 2020 Jun 5. PMID: 32415787.

81. Government of the Netherlands. Environmental data compendium. Surface water in the Netherlands. Available at: https://www.clo.nl/indic atoren/nl1401-oppervlaktewater-in-nederland Accessed Aug 9th 2021.

82. Lunetta P, Penttilä A, Sarna S. Water traffic accidents, drowning and alcohol in Finland, 1969-1995. Int J Epidemiol. 1998;27(6):1038-43. https://doi.org/10.1093/ije/27.6.1038.

83. Sedain B, Pant PR. Status of drowning in Nepal: a study of central police data. F1000Res. 2018;7:576. Published 2018 May 14. https://doi.org/10. 12688/f1000research.14563.2.

84. Jagnoor J, Lukaszyk C, Baset KU, Ivers R, Easmin S, Rahman A. Context of water transport related drownings in Bangladesh: a qualitative study. BMC Public Health. 2019;19(1):1567. Published 2019 Nov 27. https://doi. org/10.1186/s12889-019-7871-1.

85. Penttilä A, Pikkarainen J. Unfälle mit tödlichem Ausgang im finnischen Wasserverkehr während der Freizeit 1986-1988 [Accidents with fatal outcome in Finnish leisure boating 1986-1988]. Beitr Gerichtl Med. 1990;48:185-91.

86. Willcox-Pidgeon S, Peden AE, Franklin RC, Scarr J. Boating-related drowning in Australia: epidemiology, risk factors and the regulatory environment. J Saf Res. 2019;70:117-25. https://doi.org/10.1016/j.jsr. 2019.06.005.

87. Kaustell KO, Mattila TE, Rautiainen RH. Occupational injuries and diseases among commercial fishers in Finland 1996-2015. Int Marit Health. 2016;67(3):163-70. https://doi.org/10.5603/IMH.2016.0031 PMID: 27681217.

88. Kobusingye O, Tumwesigye NM, Magoola J, Atuyambe L, Olange O. Drowning among the lakeside fishing communities in Uganda: results of a community survey. Int J Inj Control Saf Promot. 2017;24(3):363-70. https://doi.org/10.1080/17457300.2016.1200629.

89. Whitworth $\mathrm{HS}$, Pando J, Hansen C, et al. Drowning among fishing communities on the Tanzanian shore of lake Victoria: a mixed-methods study to examine incidence, risk factors and socioeconomic impact. BMJ Open. 2019;9(12):e032428. Published 2019 Dec 15. https://doi.org/ 10.1136/bmjopen-2019-032428.

90. Lam RPK, Wong RTM, Lau EHY, Wong KW, Cheung ACK, Chaang VK, et al. Injury patterns of mass casualty incidents involving high-speed passenger ferries presenting to accident and emergency departments in Hong Kong: a retrospective review. Injury. 2020;51(2):252-9. https:// doi.org/10.1016/j.injury.2019.12.001 Epub 2019 Dec 2. PMID: 31836173.

91. Carter T, John A, Williams JG, Roberts SE. Suicide, fatal injuries and drowning among the crews of United Kingdom and Bermuda registered cruise and passenger ships from 1976 to 2018. Int Marit Health. 2020;71(1):12-9. https://doi.org/10.5603/IMH.2020.0006 PMID: 32212143.

92. Eriksson A, Björnstig U. Fatal snowmobile accidents in northern Sweden. J Trauma. 1982;22(12):977-82. https://doi.org/10.1097/00005373198212000-00001.

93. Oström M, Eriksson A. Snowmobile fatalities aspects on preventive measures from a 25-year review. Accid Anal Prev. 2002;34(4):563-8.

94. Wintemute GJ, Kraus JF, Teret SP, Wright MA. Death resulting from motor vehicle immersions: the nature of the injuries, personal and environmental contributing factors, and potential interventions. Am J Public Health. 1990;80(9):1068-70. https://doi.org/10.2105/ajph.80.9. 1068.

95. Stjernbrandt A, Oström M, Eriksson A, Björnstig U. Land motor vehiclerelated drownings in Sweden. Traffic Inj Prev. 2008;9(6):539-43. https:// doi.org/10.1080/15389580802339150.

96. McDonald GK, Giesbrecht GG. Vehicle submersion: a review of the problem, associated risks, and survival information. Aviat Space Environ Med. 2013;84(5):498-510. https://doi.org/10.3357/asem.3151.2013. 
97. Agócs MM, Trent RB, Russell DM. Activities associated with drownings in Imperial County, CA, 1980-90: implications for prevention. Public Health Rep. 1994;109(2):290-5.

98. Yale JD, Cole TB, Garrison HG, Runyan CW, Ruback JK. Motor vehiclerelated drowning deaths associated with inland flooding after hurricane Floyd: a field investigation. Traffic Inj Prev. 2003;4(4):279-84. https://doi.org/10.1080/714040485.

99. LTB K. Omvang, aard, en ernst van ongevallen met autito's te water. Een analyse met gegevens tot 2000. SWOV Leidschendam: SWOV report R2002-281; 2002. Available at https://www.swov.nl/publicatie/omvangaard-en-ernst-van-ongevallen-met-autos-te-water

100. Floor C, Eriks M, Collard D. Risicofactoren van verdrinking in Nederland. Utrecht: Mulier Instituut; 2019. Available at: https://www.mulierinst ituut.nl/publicaties/24730/risicofactoren-van-verdrinking-in-nederland/ Accessed Aug $9^{\text {th }} 2021$

101. Institute for Road Safety Research (SWOV). Factsheet. SWOV, The Hague 2020. Available at: https://www.swov.nl/en/facts-figures/factsheet/ road-deaths-netherlands Accessed Aug 9th 2021.

102. Garssen MJ, Hoogenboezem J, Bierens JJ. Afname van het verdrinkingsrisico bij jonge kinderen, maar verhoogd risico bij kinderen van recent geïmmigreerde niet-westerse allochtonen [reduction of the drowning risk for young children, but increased risk for children of recently immigrated non-westerners]. Ned Tijdschr Geneeskd. 2008;152(21):1216-20.

103. van Oostrum IE, Goosen ES. Afname van het verdrinkingsrisico bij jonge kinderen, maar verhoogd risico bij kinderen van recent geïmmigreerde niet-westerse allochtonen [Reduction of the drowning risk for young children, but increased risk for children of recently immigrated nonWesterners]. Ned Tijdschr Geneeskd. 2008;152(34):1896

104. Moran K. (2011) (young) men behaving badly: dangerous masculinities and risk of drowning in aquatic leisure activities. Ann Leis Res. 2011;14(2-3):260-72. https://doi.org/10.1080/11745398.2011.615719.

105. Quan L. Risk factors for drowning. Culture and ethnicity. In JJLM Bierens, editor. Drowning prevention, rescue, treatment. Heidelberg: Springer Verlag Heidelberg; 2014. p. 127-30.

106. Van Driel J. Effects of an educational intervention to increase water safe behavior amongst 10-12 year olds in the Netherlands. Utrecht: University of Utrecht. Master Thesis; 2017

107. Nasrullah M, Muazzam S. Drowning mortality in the United States, 1999-2006. J Community Health. 2011;36(1):69-75. https://doi.org/10. 1007/s10900-010-9281-2.

108. Schyllander J, Janson S, Nyberg C, Eriksson UB, Stark ED. Case analyses of all children's drowning deaths occurring in Sweden 1998-2007. Scand J Public Health. 2013;41(2):174-9. https://doi.org/10.1177/14034 94812471156.

109. Gilchrist J, Parker EM. Racial and ethnic disparities in fatal unintentional drowning among persons less than 30 years of age--United States, 1999-2010. J Safety Res. 2014;50:139-42. https://doi.org/10.1016/j.jsr. 2014.06.001 or: Gilchrist J, Parker EM; Centers for Disease Control and Prevention (CDC). Racial/ethnic disparities in fatal unintentional drowning among persons aged $\leq 29$ years - United States, 1999-2010. MMWR Morb Mortal Wkly Rep. 2014;63(19):421-426.

110. Gallinger ZR, Fralick M, Hwang SW. Ethnic differences in drowning rates in Ontario. Canada J Immigr Minor Health. 2015;17(5):1436-43. https:// doi.org/10.1007/s10903-014-0095-7.

111. Westermann CJ, Marck KW, Kroon TA. Neardrowning in seawater (curacao). Acta Tuberc Pneumol Belg. 1979;70(3-4):303-11 PMID: 262939.

112. Harada SY, Goto RS, Nathanson AT. Analysis of lifeguard-recorded data at Hanauma Bay. Hawaii Wilderness Environ Med. 2011;22(1):72-6. https://doi.org/10.1016/j.wem.2010.10.012 Epub 2010 Nov 3. PMID: 21377124.

113. Stewart BT, Yankson IK, Afukaar F, Medina MC, Cuong PV, Mock C. Road traffic and other unintentional injuries among travelers to developing countries. Med Clin North Am. 2016;100(2):331-43. https://doi.org/10 1016/j.mcna.2015.07.011.

114. Peden AE, Franklin RC, Leggat PA. International travelers and unintentional fatal drowning in Australia--a 10 year review 2002-12. J Travel Med. 2016;23(2):tav031. Published 2016 Feb 15. https://doi.org/10. 1093/jtm/tav031.

115. Willcox-Pidgeon S, Kool B, Moran K. Perceptions of the risk of drowning at surf beaches among New Zealand youth. Int J Inj Control Saf Promot.
2018;25(4):365-71. https://doi.org/10.1080/17457300.2018.1431939 Epub 2018 Feb 8. PMID: 29415615

116. Royal Life Saving Australia National Drowning Report 2019-2020. Available at: https://royallifesavingwa.com.au/news/community/natio nal-drowning-report-2020 Accessed Aug 9th 2021.

117. Reddingsbrigades Nederland Jaarverslag 2019 (Royal Lifesaving The Netherlands Year report 2019). Available at: https://www.google.nl/ search?client=safari\&channel=ipad_bm\&source=hp\&ei=c5_rX56P Foj0kwXY5LZAAQ\&q=jaarverslag+reddingsbrigads+Nederland\&oq= jaarverslag+reddingsbrigads+Nederland\&gs_lcp $=C g Z w c 3 k t Y W I Q A z \mid$ HCCEQChCgAToLCAAQsQMQxwEQowl6CAgAEMcBEK8BOgIIADoFC AAQsQM6CAgAEMcBEKMCOgUILhCXAzoCCC46CAguELEDEIMBOgg IABCXAxCDAToKCAAQsQMQgwEQCjoECAAQCjoGCAAQChAeOggIA BAFEAoQHjoGCAAQFhAeOgYIABANEB46BQghEKABUNIOWKSYAWD onAFoC3AAeACAAX6IAekWkgEENDUuMpgBAKABAaoBB2d3cy13a XqwAQA\&sclient $=$ psy-ab\&ved $=0$ ahUKEwjelJiOkfTtAhUI-qQKHVgyDxg Q4dUDCAo\&uact $=5$ Accessed Aug $9^{\text {th }} 2021$

118. Reijnen G, van de Westeringh M, Buster MC, Vos PJE, Reijnders ULJ. Epidemiological aspects of drowning and non-fatal drowning in the waters of Amsterdam. J Forensic Legal Med. 2018;58:78-81. https://doi. org/10.1016/j.jflm.2018.04.014.

119. ANAMORT - EUROSTAT. Drowning related death in an enlarged European Union. Available at: https://www.google.nl/search?q= ANAMORT+data+drowning\&client=safari\&channel=ipad_bm\&ei= ZnZQYMeUHJbYsAen 15OYAg\&oq=ANAMORT+data+drowning\& gs_lcp $=$ Cgdnd3Mtd2I6EANQ3PgBWPqCAmCplAJoAXAAeACAAUelA elEkgECMTCYAQCgAQGqAQdnd3Mtd2|6wAEB\&sclient=gws-wiz\& ved=0ahUKEwjH35OVvLTVAhUWLOwKHafrBCMQ4dUDCAw\&uact=5. Accessed Aug $9^{\text {th }} 2021$

120. Chang SSM, Ozanne-Smith J. Drowning mortality in children aged 0-14 years in Victoria, Australia: detailed epidemiological study 2001-2016. In Prev. 2020;26(6):593-8. https://doi.org/10.1136/injuryprev-2019-043307 Epub 2019 Aug 17. PMID: 31422366.

121. Yin Z, Wu J, Luo J, Pak AW, Choi BC, Liang X. Burden and trend analysis of injury mortality in China among children aged 0-14 years from 2004 to 2011. BMJ Open. 2015;5(7):e007307 Published 2015 Jul 2. https://doi. org/10.1136/bmjopen-2014-007307

122. Wang $L$, Cheng $X$, Yin $P$, et al. Unintentional drowning mortality in China, 2006-2013. Inj Prev. 2019;25(1):47-51. https://doi.org/10.1136/ injuryprev-2017-042713.

123. Nguyen $\mathrm{H}$, Ivers $\mathrm{RQ}$, Pham $\mathrm{C}$, Jagnoor J. Trends of drowning mortality in Vietnam: evidence from the national injury mortality surveillance system. Inj Prev. 2020;26(1):42-8. https://doi.org/10.1136/injur yprev-2018-043030.

124. Derakhshan P, Saeedi Moghaddam S, Saadat S, et al. Trends in the drowning mortality rate in Iran. Inj Prev. 2020;26(4):351-9. https://doi. org/10.1136/injuryprev-2019-043225.

125. Tan RM. The epidemiology and prevention of drowning in Singapore. Singap Med J. 2004;45(7):324-9.

126. Staines C, Ozanne-Smith J. Drowning deaths between 1861 and 2000 in Victoria. Aust Bull World Health Organ. 2017;95(3):174-81. https://doi. org/10.2471/BLT.16.174425.

127. Tyler MD, Richards DB, Reske-Nielsen C, et al. The epidemiology of drowning in low- and middle-income countries: a systematic review. BMC Public Health. 2017;17(1):413. Published 2017 May 8. https://doi. org/10.1186/s12889-017-4239-2.

128. van Hemert AM, de Kruif M. Dalende incidentie van zelfdoding en veranderende methoden [decreasing incidence of suicide in the Netherlands, with changing methods]. Ned Tijdschr Geneeskd. 2009;153:B384.

129. Bierens JJ, van der Velde EA, van Berkel M, van Zanten JJ. Submersion cases in the Netherlands. Ann Emerg Med. 1989;18(4):366-73. https:// doi.org/10.1016/s0196-0644(89)80571-2.

130. Felton $\mathrm{H}$, Myers J, Liu G, Davis DW. Unintentional, non-fatal drowning of children: US trends and racial/ethnic disparities. BMJ Open. 2015;5(12):e008444. Published 2015 Dec 15. https://doi.org/10.1136/ bmjopen-2015-008444.

131. Umapathi KK, Thavamani A, Dhanpalreddy H, Khatana J, Roy A. Incidence trends and predictors of in-hospital mortality in drowning in children and adolescents in the United States: a National Inpatient 
Database Analysis. Clin Pediatr (Phila). 2020;59(2):134-41. https://doi. org/10.1177/0009922819886871.

132. Idris AH, Bierens JJLM, Perkins GD, Wenzel V, Nadkarni V, Morley P, et al. 2015 revised Utstein-style recommended guidelines for uniform reporting of data from drowning-related resuscitation: an ILCOR advisory statement. Circ Cardiovasc Qual Outcomes. 2017;10(7):e000024. https:// doi.org/10.1161/HCQ.0000000000000024 PMID: 28716971; PMCID: PMC6168199.

133. Venema AM, Absalom AR, Idris AH, Bierens JJLM. Review of 14 drowning publications based on the utstein style for drowning. Scand J Trauma Resusc Emerg Med. 2018;26(1):19. https://doi.org/10.1186/ s13049-018-0488-z PMID: 29566700; PMCID: PMC5863818.

134. United Nations General Assembly Resolution on drowning prevention. Available at: https://documents-dds-ny.un.org/doc/UNDOC/LTD/N21/ 091/81/PDF/N2109181.pdf?OpenElement. Accessed at: Aug $9^{\text {th }} 2021$.

\section{Publisher's Note}

Springer Nature remains neutral with regard to jurisdictional claims in published maps and institutional affiliations.

- fast, convenient online submission

- thorough peer review by experienced researchers in your field

- rapid publication on acceptance

- support for research data, including large and complex data types

- gold Open Access which fosters wider collaboration and increased citations

- maximum visibility for your research: over $100 \mathrm{M}$ website views per year

At BMC, research is always in progress.

Learn more biomedcentral.com/submissions 